\title{
PCR for detection of virulence and antibiotic resistance genes of coagulase positive staphylococcus aureus from clinical mastitis in Egypt
}

\author{
Eman Abdeen, $\mathrm{E}^{1 *}$, Mousa Walid ${ }^{2}$, Heba Hussien ${ }^{3}$, Saher Roshdy ${ }^{4}$ \\ ${ }^{1}$ Department of bacteriology, mycology and immunology \\ ${ }^{2}$ Department of animal medicine and infectious diseases \\ ${ }^{3}$ Department of Food Hygiene \& Control, Faculty of Veterinary Medicine, University of Sadat City \\ ${ }^{4}$ Animal health research institute, Dokki, Giza, Egypt \\ *Corresponding author E-mail: eman.abdeen2014@yahoo.com
}

Copyright $(2015$ Eman Abdeen, $\mathbf{E}$ et al. This is an open access article distributed under the Creative Commons Attribution License, which permits unrestricted use, distribution, and reproduction in any medium, provided the original work is properly cited.

\begin{abstract}
Coagulase positive Staphylococcus aureus is the most frequently bacterial pathogen causing clinical mastitis in cattle. In this work, 120 milk samples were collected from cattle suffering from clinical mastitis. The results revealed that S. aureus was 35 isolates $(29.16 \%)$ and other staphylococci were 13 isolates $(10.84 \%)$. The application of PCR was effectively in detection of Coa. SpA, mecA and blaZ genes of $S$. aureus by amplification at a single amplicon at $630 \mathrm{bp}, 226 \mathrm{bp}, 310 \mathrm{bp}$ and 173bp, respectively. The results concluded that the detection of Coa and SpA genes can be used as a good method for typing of $S$. aureus strains as well as the detection of antibiotic resistance mecA and blaZ genes may be helpful for effective control of staphylococcal mastitis.
\end{abstract}

Keywords: COA; SPA; MECA; BLAZ; PCR; Staphylococcus aureus; Mastitis

\section{Introduction}

Mastitis is recognized as the most important dairy herd problem worldwide [1]. Economic losses of mastitis include decrease in milk quantity \& quality and high costs of treatment [2]. S. aureus is one of the most common etiological pathogens, causing intramammary infection in dairy herds leading to severe economic losses in dairy industry [3] which colonize in the mammary gland [4]. S. aureus produce a large number of potential virulence factors which have an important role in the pathogenesis of mastitis [5].These include, Coagulase which is considered the most important virulence factor that clot plasma and coats the bacterial cell, so prevent the phagocytosis [6] via enables staphylococci to captured within a fibrin meshwork, disseminate and resist opsonophagocytic mechanism of host immune cells [7]. Staphylococcal protein A (spA) is a membrane-bound exoprotein of bacterial cell wall which considered an important virulence factor that impair opsonization by serum complement and phagocytosis of Polymorphonuclear leukocytes through binding to FC region of immunoglobulins [8]. S.aureus developed a high resistant against a wide variety of antibiotics which increase their virulence and difficulty in treatment [9]. The most important antibiotic resistant genes of S.aureus strains was blaZ gene which coded for $\beta$-lactamase. [10] and mecA gene which designated for methicillin resistance (MRSA) that coded for penicillin-binding protein 2a [11]. From epidemiological point of view the presence of virulent strains of $S$.aureus in mastitic milk give an importance to detect and characterize of these strains to control and reduction of the disease dissemination in dairy herds [12]. Therefore, this research was planned for characterization of $S$. aureus and detection of their virulence and antibiotic resistance genes from clinical mastitis cases. 


\section{Material and methods}

1) Collection of milk samples according to [13]:

A total of 120 mastitic milk samples were collected from clinical cases of mastitis of lactating cattle at Menofia and

Beheria Governorate from small-holders farmers.

2) Phenotypic characterization: through culturing onto blood agar, Baired parker agar medium and Gram's staining for demonstrating characteristic shape of staphylococci according to [14].

3) Biochemical and virulence activities:

All suspected strains of Staphylococci tested for catalase, tube coagulase using rabbit plasma [15], haemolysis on blood agar and Deoxyribonuclease (DNase) activity onto DNase agar [16]:

4) PCR detection of Coa, spA, blaZ and mecA genes of $S$. aureus.

DNA extraction. DNA extraction from samples was performed using the QIAamp DNA Mini kit (Qiagen, Germany, $\mathrm{GmbH}$ ) with modifications from the manufacturer's recommendations. Briefly, $200 \mu 1$ of the sample suspension was incubated with $10 \mu \mathrm{l}$ of proteinase $\mathrm{K}$ and $200 \mu \mathrm{l}$ of lysis buffer at $56^{\circ} \mathrm{C}$

for $10 \mathrm{~min}$. After incubation, $200 \mu \mathrm{l}$ of $100 \%$ ethanol was added to the lysate. The sample was then washed and centrifuged following the manufacturer's recommendations. Nucleic acid was eluted with $100 \mu$ of elution buffer provided in the kit.

Oligonucleotide Primer. Primers used were supplied from Metabion (Germany) are listed in table (1).

PCR amplification. Primers were utilized in a 25- $\mu 1$ reaction containing $12.5 \mu 1$ of Emerald Amp Max PCR Master Mix (Takara, Japan), $1 \mu \mathrm{l}$ of each primer of 20 pmol concentrations, $4.5 \mu \mathrm{l}$ of water, and $6 \mu \mathrm{l}$ of DNA template. The reaction was performed in an applied biosystem 2720 thermal cycler.

\section{Analysis of the PCR products}

The products of PCR were separated by electrophoresis on 1.5\% agarose gel (Applichem, Germany, GmbH) in 1x TBE buffer at room temperature using gradients of $5 \mathrm{~V} / \mathrm{cm}$. For gel analysis, $15 \mu \mathrm{l}$ of the products was loaded in each gel slot. A $100 \mathrm{bp}$ and 100DNA Ladders (Qiagen, Germany, GmbH) was used to determine the fragment sizes. The gel was photographed by a gel documentation system (Alpha Innotech, Biometra), and the data was analyzed through computer software.

Table 1: Primers Sequences, Target Genes, Amplicon Sizes and Cycling Conditions.

\begin{tabular}{|c|c|c|c|c|c|c|c|c|}
\hline \multirow{2}{*}{$\begin{array}{l}\text { Target } \\
\text { gene }\end{array}$} & \multirow[b]{2}{*}{ Primers sequences } & \multirow{2}{*}{$\begin{array}{l}\text { Amplified } \\
\text { segment } \\
\text { (bp) }\end{array}$} & \multirow{2}{*}{$\begin{array}{l}\text { Primary } \\
\text { denaturation }\end{array}$} & \multicolumn{3}{|c|}{ Amplification (35 cycles) } & \multirow{2}{*}{$\begin{array}{l}\text { Final } \\
\text { extension }\end{array}$} & \multirow[b]{2}{*}{ Reference } \\
\hline & & & & $\begin{array}{l}\text { Secondary } \\
\text { denaturation }\end{array}$ & Annealing & Extension & & \\
\hline $\operatorname{mec} A$ & $\begin{array}{l}\text { GTA GAA ATG ACT GAA CGT } \\
\text { CCG ATA A } \\
\text { CCA ATT CCA CAT TGT TTC } \\
\text { GGT CTA A }\end{array}$ & 310 & $\begin{array}{l}94^{\circ} \mathrm{C} \\
5 \mathrm{~min} .\end{array}$ & $\begin{array}{l}94^{\circ} \mathrm{C} \\
45 \mathrm{sec} .\end{array}$ & $\begin{array}{l}50^{\circ} \mathrm{C} \\
45 \mathrm{sec} .\end{array}$ & $\begin{array}{l}72^{\circ} \mathrm{C} \\
45 \mathrm{sec} .\end{array}$ & $\begin{array}{l}72^{\circ} \mathrm{C} \\
10 \mathrm{~min} .\end{array}$ & [17] \\
\hline spa & $\begin{array}{l}\text { TCA ACA AAG AAC AAC AAA } \\
\text { ATG C } \\
\text { GCT TTC GGT GCT TGA GAT } \\
\text { TC }\end{array}$ & 226 & $\begin{array}{l}94^{\circ} \mathrm{C} \\
5 \mathrm{~min} .\end{array}$ & $\begin{array}{l}94^{\circ} \mathrm{C} \\
30 \mathrm{sec} .\end{array}$ & $\begin{array}{l}55^{\circ} \mathrm{C} \\
30 \mathrm{sec} .\end{array}$ & $\begin{array}{l}72^{\circ} \mathrm{C} \\
30 \mathrm{sec} .\end{array}$ & $\begin{array}{l}72^{\circ} \mathrm{C} \\
10 \mathrm{~min} .\end{array}$ & {$[18]$} \\
\hline Coagulase & $\begin{array}{l}\text { ATA GAG ATG CTG GTA CAG } \\
\text { G }\end{array}$ & $\begin{array}{l}\text { Four } \\
\text { different } \\
\text { types of } \\
\text { bands may } \\
\text { be detected } \\
350 \mathrm{bp} \\
430 \mathrm{bp} \\
570 \mathrm{bp} \\
630 \mathrm{bp}\end{array}$ & $\begin{array}{l}94^{\circ} \mathrm{C} \\
10 \mathrm{~min} .\end{array}$ & $\begin{array}{l}94^{\circ} \mathrm{C} \\
1 \mathrm{~min} .\end{array}$ & $\begin{array}{l}55^{\circ} \mathrm{C} \\
1 \mathrm{~min} .\end{array}$ & $\begin{array}{l}72^{\circ} \mathrm{C} \\
1 \mathrm{~min} .\end{array}$ & $\begin{array}{l}72^{\circ} \mathrm{C} \\
10 \mathrm{~min}\end{array}$ & [19] \\
\hline blaZ & $\begin{array}{l}\text { ACTTCAACACCTGCTGCTTTC } \\
\text { TGACCACTTTTATCAGCAACC }\end{array}$ & $173 \mathrm{bp}$ & $\begin{array}{l}94^{\circ} \mathrm{C} \\
5 \mathrm{~min} .\end{array}$ & $\begin{array}{l}94^{\circ} \mathrm{C} \\
30 \mathrm{sec} .\end{array}$ & $\begin{array}{l}54^{\circ} \mathrm{C} \\
30 \mathrm{sec} .\end{array}$ & $\begin{array}{l}72^{\circ} \mathrm{C} \\
30 \mathrm{sec} .\end{array}$ & $\begin{array}{l}72^{\circ} \mathrm{C} \\
7 \mathrm{~min} .\end{array}$ & {$[20]$} \\
\hline
\end{tabular}




\section{Results}

Table 2: Prevalence of Staphylococci in Clinical Bovine Mastitic Cases.

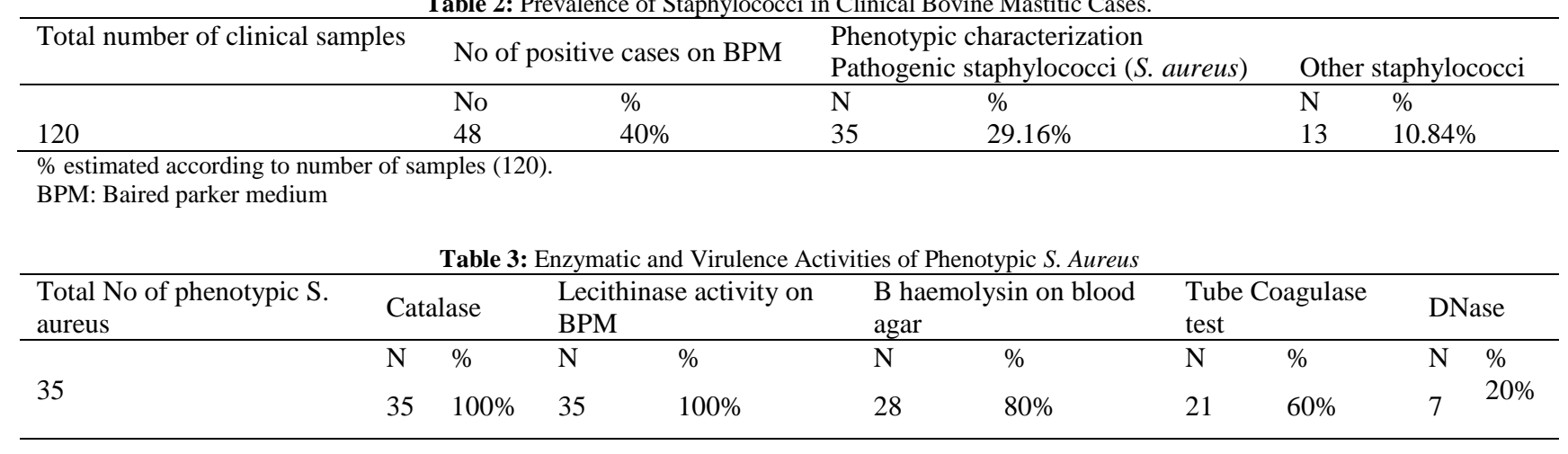

Results of Coa, SpA, mecA and blaZ genes of Staph.aureus by PCR.

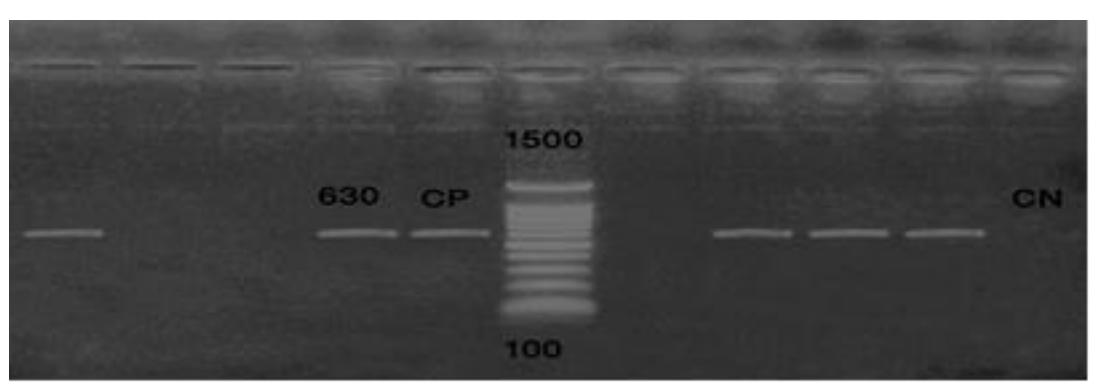

Fig. 1: 1.5\% Agarose gel electrophoresis showed positive amplification of Coa gene of $S$. aureus isolates at 630 bp Fragment (S1, 2, 3, 5, 8). Cp (Control Positive), CN (Control Negative)).

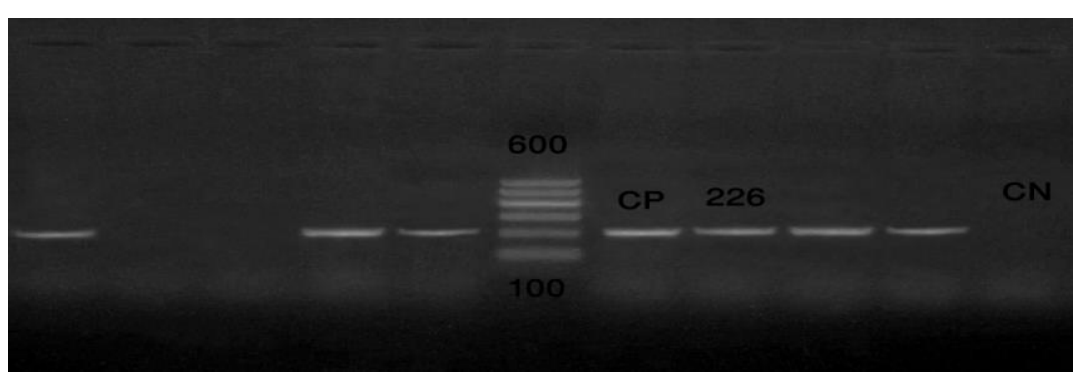

Fig. 2: 1.5\% Agarose gel electrophoresis showed positive amplification of SpA gene of $S$. aureus isolates at 226 bp Fragment (S1, 2, 3, 4, 5, 8). Cp (Control Positive), CN (Control Negative).

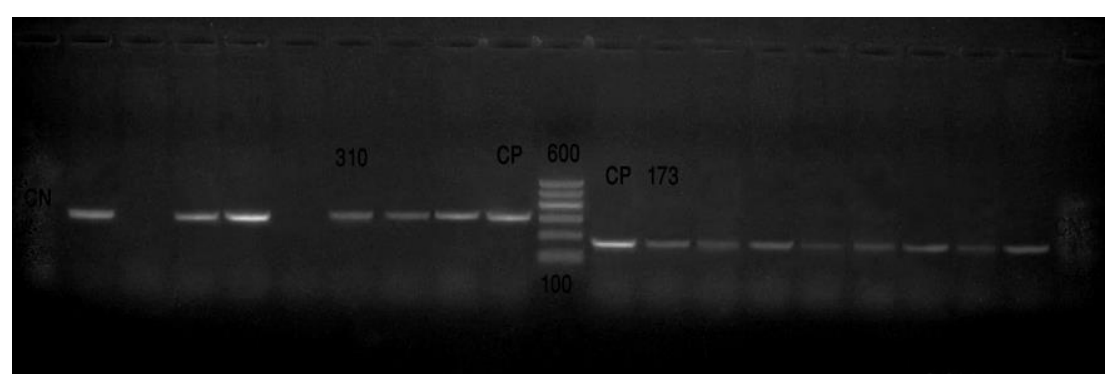

Fig. 3: $1.5 \%$ Agarose gel electrophoresis showed positive amplification of of Mec A gene at 310 bp Fragment $(\mathrm{S} 1,2,3,5,6,8)$ and blaz gene at 173bp Fragment of S. aureus isolates (S 1-8), Cp (Control Positive), CN (Control Negative)). 


\section{Discussion}

Staph.aureus is the most important bacterial microorganism in bovines causing contagious mastitis and highly economic losses in dairy herds [21]. In the present study, phenotypic characterization of S. aureus was depended on Gram's stain, culturing on Baired parker medium, Catalase, tube coagulase and DNase tests. This finding was agree with [22] all S.aureus strains were positive for coagulase test and give a typical morphology on Baird Parker agar medium. In the present study, a prevalence rate of S.aureus was (29.16\%). These results come in agreement with [23] isolated S.aureus (28.2\%) from clinical cases in cattle. Moreover [24] revealed that S.aureus is responsible for about $(30 \%)$ to $(40 \%)$ of all mastitis cases. The high prevalence in the present study may be correlated to the transmission of infection by milker's hands, contaminated equipments and bad hygienic environment in small holder cows [25]. Several virulence factors were produced by S. aureus, including Coagulase protein, which is important in the pathogenicity [26] through turn fibrinogen to fibrin, then lead to abscess formation and persistence of microorganism in host tissue [27]. Coagulase protein is considered to be a virulence factor in intrammmary infection and can be used as a simple and effective method for typing of $S$. aureus isolates from bovine mastitis. [28]. In the present study, all positive coagulase isolates subjected to Coa gene by PCR, and the result revealed that all isolates give a single amplicon at $630 \mathrm{bp}$. This nearly agree with [23] who reported a single amplicon of Coa gene at $600 \mathrm{bp}$ of isolates from bovine mastitis. Moreover, the findings reported by [29] suggested that the amplicon of about $600 \mathrm{bp}$ are predominant in bovine strains. As shown in fig (1) some isolates of CoPS didn't show any band at the set of this primer, which may be due to gene polymorphism. This finding agree with [30] achieved that S. aureus isolates give 5 different PCR products of Coa gene. Furthermore, [26] stated that coagulase gene had different PCR products indicating the polymorphism of the gene. Moreover [28] showed amplification of the coa gene of $S$. aureus isolates from mastitic cow produces 27 different PCR-products, which ranged from 579 to $1442 \mathrm{bp}$. The SpA gene is a major important surface protein of bacterial cell wall, which binds with FC region of immunoglobulin $\mathrm{G}$, so the decreasing in SpA on cell surface of $S$. aureus resulted in increasing number of free receptor sites for complement and enhance phagocytosis [31]. The present study showed amplification of SpA gene of S.aureus at 229 bp. [32] reported that $\mathrm{SpA}$ gene can be used for typing the isolates of S.aureus. Furthermore [31] the detection of genetic polymorphisms in the $\mathrm{X}$ region of the SpA gene can be used for typing of $S$. aureus. Also [33] concluded that detection of SpA gene polymorphisms with Coa-PCR is proposed as a good diagnostic method for typing of $S$. aureus isolates which provided important results for effective control of staphylococcal mastitis. Recently, the prevalence of antibiotic resistance in S. aureus strains becomes a serious problem in dairy herds [34]. In the present study, mecA gene was detected at $310 \mathrm{bp}$. [35] mentioned that mecA gene of S.aureus strains was the main gene responsible for the resistance to methicillin through the production of Penicillin binding protein (PBP2a). The resistance to $\beta$-lactam antibiotics occur through hydrolyzing the $\beta$-lactam ring and convert to inactive form, so the application of PCR for detection of blaZ gene is recommended in veterinary laboratories for detection of the resistant strains of S. aureus [36]. In our result, all isolates of S. aureus subjected to PCR were positive for blaZ gene and gave a single amplicon at $173 \mathrm{bp}$. The same result obtained by [37] detected a single amplicon of $173 \mathrm{bp}$ of blaZ gene. Our results showed that all tested strains for mecA gene were positive for blaZ gene and this similar to [38] who noticed that all positive strains to mecA were also positive for blaZ gene and the presence of both genes was correlated to phenotypic beta-lactam resistance of $S$. aureus strains.

\section{References}

[1] Dhakal, I. P.; Koshihara, T. and Nagahata, H. (2007):Epidemiological and bacteriological survey of buffalo mastitis in Nepal. J Vet Med Sci 69:1241-1245. http://dx.doi.org/10.1292/jvms.69.1241.

[2] Getahum, K.; Kelay, B.; Bekana, M. and Lobago, F. (2008): Bovine mastitis and antibiotic resistance patterns in Selalle smallholder dairy farms, central Ethiopia. Trop Anim Health Prod 40:261-268. http://dx.doi.org/10.1007/s11250-007-9090-5.

[3] Godden, S.M.; Jansen, J.T.; Leslie, K.E.; Smart, N.L. and Kelton, D.F. (2002): The effect of sampling time and sample handling on the detection of Staphylococcus aureus in milk from quarters with subclinical mastitis. Can. Vet. J. 43:38-42.

[4] Salasia, S.; Khusnan, Z.; Lammler, C. and Zschock, M. (2004): Comparative studies on pheno and genotypic properties of Staphylococcus aureus isolated from bovine subclinical mastitis in Central Java in Indonesia and Hesse in Germany. J Vet Sci, 5: 103- 109.

[5] Kalorey, D.R.; Shanmugam, Y.; Kurkure, N.V.; Chousalkar, K.K. and Barbuddhe, S.B. (2007): PCR-based detection of genes encoding virulence determinants in Staphylococcus aureus from bovine subclinical mastitis cases. J Vet Sci, 8: 151-154. http://dx.doi.org/10.4142/jvs.2007.8.2.151.

[6] Panizzi, P.; Friedrich, R.; Fuentes-Prior, P.; Bode, W. and Bock, P.E. (2004): The staphylocoagulase family of zymogen activator and adhesion proteins. Cell Mol Life Sci 61: 2793-2798. http://dx.doi.org/10.1007/s00018-004-4285-7.

[7] Mcadow, M.; Missiakas, D. M. and Schneewind, O. (2012): S.aureus secretes Coagulase and von willebrand factor binding protein to modify the coagulation cascade and establish host infections. Journal of Innate immune, 4(2):141-148.

[8] Alonso, D.O.V. and Daggett, V.( 2000): Staphylococcal Protein A: Unfolding pathways, unfolded states, and differences between the B and E domains. Proc. Natl Acad. Sci. USA 97:133-138. http://dx.doi.org/10.1073/pnas.97.1.133.

[9] Gentilini, E.; Denamiel, G.; Llorente, P.; Godaly, S.; Rebueto, M. and De Gregorio, O. (2000): Antimicrobial susceptibility testing of Staphylococcus aureus isolated from bovine mastitis in Argentina. J. Dairy Sci., 83: 1224-1227. http://dx.doi.org/10.3168/jds.S00220302(00)74988-5.

[10] Taponen, S. and Pyorala, S.(2009): Coagulase-negative Staphylococci as cause of bovine mastitis: not so different from Staphylococcus aureus? Vet Microbiol 134:29-36. http://dx.doi.org/10.1016/j.vetmic.2008.09.011. 
[11] Katayama, Y.; Robinson, D.A.; Enright, M.C. and Chambers, H. (2005): Genetic background affects stability of mecA in Staphylococcus aureus. J. Clin. Microbiol. 43:2380-2383. http://dx.doi.org/10.1128/JCM.43.5.2380-2383.2005.

[12] Cremieux, A. C.; Dumitrescu, O.; Lina, G.; Vallee, C. and Cote, J.F. (2009): Panton-valentine leukocidin enhances the severity of communityassociated methicillin-resistant Staphylococcus aureus rabbit osteomyelitis. PLoS ONE 4: e7204. http://dx.doi.org/10.1371/journal.pone.0007204.

[13] Brown, R.W.; Barnum, D.A.; Jaspar, D.B.; McDonald, J.S. and Schultze, W. D. (1981): Microbiological Procedures Used in the Diagnosis of Bovine Mastitis. 2nd Edn. National Mastitis Council, Washington, DC. USA.

[14] Quinn, P. J.; Carter, M. E.; Makrkey, B. K. and Carter, G. R. (1994): Clinical veterinary microbiology.mosby year book Europ Limited, Lynton House, London, .109-126.

[15] A.P.H.A. (1992): Standard Methods for the Examination of dairy roducts 15th. Americana public Health Association Washington, D.

[16] Murray, P. R.; Baron, E. J. and Jorgensen, J. H. (2003): Manual of Clinical Microbiology, 8th ed. American Society for Microbiology, Washington, DC.

[17] McClure, J.A.; Conly, J.M.; Lau, V.; Elsayed, S.; Louie, T.; Hutchins, W. and Zhang, K. (2006): Novel multiplex PCR assay for detection of the staphylococcal virulence marker Panton-Valentine leukocidin genes and simultaneous discrimination of methicillin-susceptible from resistant staphylococci. J Clin Microbiol 44: 1141-1144. http://dx.doi.org/10.1128/JCM.44.3.1141-1144.2006.

[18] Wada, M.; Lkhagvadorj, E.; Bian, L.; Wang, C.; Chiba, Y.; Nagata, S.; Shimizu, T.; Yamashiro, Y.; Asahara, T. and Nomoto, K. (2010): Quantitative reverse transcription-PCR assay for the rapid detection of methicillin-resistant Staphylococcus aureus. Journal of Applied Microbiology 108: 779-788. http://dx.doi.org/10.1111/j.1365-2672.2009.04476.x.

[19] Iyer, A.P. and Kumosani, T.A. (2011): PCR based detection of nosocomial infection causing MRSA (Methicillin resistant Staphylococcus aureus). 2nd International Conference on Biotechnology and Food Science IPCBEE vol.7, IACSIT Press, Singapore.

[20] Duran, N.; Ozer, B.; Duran, G.G.; Onlen, Y. and Demir, C. (2012): Antibiotic resistance genes \&susceptibility patterns in staphylococci. Indian J Med Res 135, pp 389-396.

[21] Zecconi, A.; Calvinho, L.F. and Fox, K.L.(2006): Staphylococcus aureus intramammary infections. IDF Bulletin 408, 1-42.

[22] Brown, P.D. and Ngeno, C. (2007): Antimicrobial resistance in clinical isolates of Staphylococcus aureus from hospital and community sources in southern Jamaica. International Journal of Infectious Diseases. Vol 11(3): 220-225. http://dx.doi.org/10.1016/j.ijid.2006.04.005.

[23] Enany, M. E.;Younes, S.; AL- gammal, A.M. ; Salem, M. and El Dieb, H.A.(2013): Prevalence of coagulase (coa) gene and mec A gene of S. aureus isolated from bovine clinical mastitis. Seuz Canal Veterinary Medicine Journal, XVIII (1): 147-157.

[24] Bedane, A.; Kasim, G.; Yohannis, T.; Habtamu, T.; Asseged, B. and Demelash B. (2012): Study on Prevalence and Risk Factors of Bovine Mastitis in Borana Pastoral and Agro-Pastoral Settings of Yabello District, Borana Zone, Southern Ethiopia American-Eurasian. J. Agric. \& Environ. Sci., 12 (10): 1274-1281.

[25] Scherrer, D.; Corti, S.; Muehlherr, J. E.; Zweife, C. and Stephan, R. (2004): Phenotypic and genotypic characteristics of S. aureus isolates from raw bulk-tank milk samples of goats and sheep. Veterinary Microbiology. 101:101-107. http://dx.doi.org/10.1016/j.vetmic.2004.03.016.

[26] Momtez, H.; Tajbakhsh, E.; Rahimi, E. and Momeni, M. (2011): Coagulase gene polymorphism of staphylococcus aureus isolated from clinical and subclinical mastitis in Isfahan and chaharmhal va Bakhtiari provinces of Iran. Com.Clin. Path. Vol 20 (5): 519-522. http://dx.doi.org/10.1007/s00580-010-1029-y.

[27] Mcadow, M.; Kim, H. K.; Dedent, A. C.; Hendrickx, A. P.; Schneewind, O. and Missiakas, M.(2011):Preventing Staphylococcus aureus sepsis through the inhibition of its agglutination in blood. PLoS Pathog. 7, e1002307. http://dx.doi.org/10.1371/journal.ppat.1002307.

[28] Da Silva, E.R. and Da Silva, N. (2005): Coagulase gene typing of Staphylococcus aureus isolated from cows with mastitis in southern Brazil. Canadian. J. Vet. Res. 69: 260-264.

[29] Cabral, K.G.; Lammler, C.; Zschock, M.; Langoni, H.; De Sa Me, Victoria, C. and Da Silva , A.( 2004): Pheno- and genotyping of Staphylococcus aureus, isolated from bovine milk samples from Sao Paulo State, Brazil. Can. J. Microbiol. 50(11):901-909. http://dx.doi.org/10.1139/w04-082.

[30] Aslantas, O.; Demir, C.; Türütoglu , H.; Cantekin, Z.; Ergün, Y. and Dogruer, G. (2007): Coagulase Gene polymorphism of Staphylococcus aureus isolated from subclinical bovine mastitis. Turk. J. Vet. Anim. Sci. 31(4):253-257.

[31] GAO, J. and Stewart, G.C. (2004): Regulatory elements of the Staphylococcus aureus protein A (Spa) promoter. J Bacteriol, $186: 3738-3748$. http://dx.doi.org/10.1128/JB.186.12.3738-3748.2004.

[32] Gholamreza Feizi, M.A.H.; Zarrini, G. and Tahmasebi, M. (2013): Evaluation of Protein a Gene Tandem Repeat Polymorphism of Staphylococcus aureus isolated From Bovine Mastitis in Tabriz. Jundishapur Journal of Microbiology. Vol 6(6): e7934.

[33] Karahan, M.; Acik, M. N. and Cetinkaya, B. (2011): Investigation of virulence genes by PCR in Stapylococcus aureus isolates originated from subclinical bovine mastitis in Turkey. Pak Vet J, 31(3): 249-253.

[34] Wang, Y.; Wu, C.M.; Lu, L.M.; Ren, G.W.; Cao, X.Y. and Shen, J.Z. (2008): Macrolide-lincosamide-resistant phenotypes and genotypes of Staphylococcus aureus isolated from bovine clinical mastitis. Vet Microbiol 130: 118-125. http://dx.doi.org/10.1016/j.vetmic.2007.12.012.

[35] Ito,T.; Okuma, K.; Ma, X.; Yuzawa, H. and Hiramatsu, K. (2003): Insights on antibiotic resistance of S.aureus from its whole genome .genomic island SCC. Microb. Drug. Resist. 6:41-52. http://dx.doi.org/10.1016/S1368-7646(03)00003-7.

[36] Kernodle, D. S. (2000): Mechanism of resistance to Beta-lactam antibiotics in Gram-positive Pathogens. American Society of Microbiology, Washington, DC, USA.Pp.609-620.

[37] Chandrasekaran, D.; Venkatesan, P.; Tirumurugaan, K.G.; Subapriya, S.; Nambi, A.P; Thirunavukkarasu, P.S. And Vairamuthu, S. (2014): Comparison of tests for detection of lactamase staphylococcus aureus in mastitis cows: International Journal of Science, Environment and Technology, Vol. 3, No: $1525-1527$.

[38] Soares, L.C.; Pereira, I.A.; Pribul, B.R.; Oliva, M.S.; Coelho, S.M.O. and Souza, M.M.S. (2012): Antimicrobial resistance and detection of mecA and blaZ genes in coagulase-negative Staphylococcus isolated from bovine mastitis. Pesq. Vet. Bras. 32(8):692-696. http://dx.doi.org/10.1590/S0100-736X2012000800002. 